\title{
Belarus: from a Social Contract to a Security Contract?
}

\author{
BY
}

ANDREW WILSON

In 2014 Aliaksandr Lukashenka reached his twentieth anniversary as President of Belarus, prompting a series of analyses of just how he had managed to survive in power for so long. The best of these need only refinement. Margarita Balmaceda, for example looks, at how Lukashenka has both extracted rent from Russia by exploiting his foreign policy value and used it skilfully to consolidate his hold on power. Russian subsidies maintain the Belarusian economy; but, she writes, 'while financial support from Russia has been key (in which access to external energy rents played an important role), no less important is the way these rents were used domestically' (Balmaceda 2014a, 515). Other studies by Pranevičiūtè-Neliupšienè and Maksimiuk (2014, 124-156), Ioffe (2014; Ioffe and Yarashevich 2011) and Yarashevich (2014) of what might be called 'distributional authoritarianism' have looked at the regime's spending on social goods to maintain baseline popularity and keep the level of coercion lower than it would be otherwise.

Ironically, however, this analysis came at the very time when the old paradigm was changing. The war in Ukraine, Russia's increasingly problematic relations with all of its neighbours and Russia's own economic troubles put both the subsidy regime and Lukashenka's foreign policy balancing game in doubt. Lukashenka won official re-election in 2015; but this was the first time he had held an election in a recession, with the supply of social goods under threat. The maintenance of statehood and national security have suddenly become a much more prominent part of his governing formula, but it remains to be seen how secure that will make his rule in the future.

In other words, just when we had some pretty good answers to explain how Belarus works and how Lukashenka has survived for so long, we need to know more.

\section{Economic Risks}

Belarus has had three recessions since 2008. The first was in the global recession year of 2009. The second came after an unsustainable spending surge to 
get Lukashenka through the 2010 election. Official statistics still showed growth in 2011 , but the Belarusian rouble lost $60 \%$ of its value and inflations topped $108 \%$ in a crisis atmosphere, until a Russian bail-out was agreed in November 2011. This briefly restored the system whereby Russian subsidies provided 15$16 \%$ of Belarusian GDP (Aliachnovič 2015). But once Russia was hit by economic sanctions after its aggression against Ukraine in 2014, it could no longer afford to be so generous. With relations with the IMF on ice since 2010 , only $\$ 800$ million came in 2016 from the Russia-led Eurasian Fund.

Belarus also lost exports to Russia and Ukraine as both countries suffered GDP loss, only partly compensated by some import switching and re-routing and re-labelling of goods under EU sanction. An anaemic recovery in Belarus in 2012-13 was therefore followed by a much-deeper recession beginning in 2014, compounded by the fall in the oil price.

But Lukashenka rejected root-and-branch reform in his fifth inauguration speech in November 2015: arguing that «This would mean smashing the political system, the entire government of Belarus, in pieces, dividing and giving away the state and people's property" (Deutsche Welle 2015). Nevertheless, money-saving reforms have been inevitable; state employment and pensions were gradually trimmed through 2014-16.

Belarusian GDP Growth, 2009-2017 (source: World Bank, IMF)

\begin{tabular}{|c|c|}
\hline 2009 & 0.2 \\
\hline 2010 & 7.7 \\
\hline 2011 & 5.5 \\
\hline 2012 & 1.7 \\
\hline 2013 & 1.1 \\
\hline 2014 & 1.7 \\
\hline 2015 & -3.9 \\
\hline 2016 & -2.7 \\
\hline 2017 & 0.4 \\
\hline
\end{tabular}

\section{Security Risks}

Belarus has also had to reassess its security situation since 2014. Despite Minsk being a traditional ally of Moscow, all of Russia's neighbours, friend or foe, were shaken by the assault on Ukrainian sovereignty beginning in 2014. And Russia clearly has an option on 'Operation Belarus'. Russian nationalists have been given license to criticise Lukashenka for his lack of loyalty, and his shift towards, or firmer embrace of, 
some kind of statist nationalism, since 2014. Networks like zapadrus.su and imperiya. by are promoting the old nineteenth century idea of Belarus as 'West Russia', and have attacked 'Litvinism' - depicting the idea of an independent and Western Belarus as an artificial emanation of the 'foreign' Grand Duchy of Litva (normally mislabelled in English as the Grand Duchy of Lithuania) (Popov 2016). Periodic trade wars, despite Belarus being a member of the Eurasian Economic Union, have ratcheted up the tension. The row over the military base at Babruisk rumbles on. Belarus does not yet face the threat of 'hybrid war', but according to one commentator 'there has lately been an outburst of activity from various previously dormant [pro-Russian] organisations in Belarus. These include Cossack organisations, unions of Afghan war veterans, Orthodox youth camps, patriotic military clubs, and others' (Karatch 2016a).

Belarus does not have any obvious pro-Russian redoubt, like Crimea or the Donbas. It does not have any equivalent of the Yanukovych 'Family' making trouble. But the Orthodox Church is seen as too pro-Russian (Lukashenka was angry that he was not even consulted when an ethnic Russian was appointed to head the Church in 2013), and has been linked to the growing number of 'Cossack' and veterans' groups.

Underlying all this is the broader problem that the old foreign policy paradigm has broken down. Belarus had a 'balanced' foreign policy, but its primary relationship was with Russia, where as Balmaceda put it, Belarus had two main strategies to extract resources: playing up to Russia's collective self-esteem and selling the idea of the 'ally of last resort'. Both strategies were predicated on there being only one axis of hostility, between Russia and the West. Then, according to Balmaceda, 'a certain regularity could be observed: every time relations between Russia and the West worsened, the relative value of Belarus as an ally increased' (Balmaceda 2014b, 120).

But now there are two lines of tension - between Russia and the West and between Russia and its neighbours. So the old foreign policy position of maximum advantage for Belarus - that Belarus is a pro-Russian power with autonomy to act in its own interests - is now seen in Moscow as the position of an insufficiently enthusiastic ally and a potential defector. And Belarus cannot simply return to the position of 'ally of last resort' because it has to think about its own national security first.

Lukashenka changed the military doctrine in 2015 to guard against any appearance of 'little green men' in Belarus. As it now reads, the 'sending of armed groups, irregular armed forces, mercenary groups, or regular armed forces who use arms against the Republic of Belarus by a foreign country or countries or on behalf of a foreign country or countries' will trigger a declaration of war (Coalson and Jozwiak, 2015). In 2016 a revised version talked of the dual threat of 'hybrid warfare' and 'colour revolutions', but with the implication that Russia could exploit the latter. 
Defence spending is edging up, from 1.6\% of GDP in 2012 to $1.97 \%$ in 2014 (\$710 million in total, though $\$ 640$ million net). There are 59,500 service personnel, including 46,000 soldiers and 13,000 civilians. Plans to build a 120,000-strong territorial defence force out of 350,000 reservists may prove a pipe-dream, however, like most 'people's militias'.

But Belarus is at least quantitatively and qualitatively better off than Ukraine in early 2014, despite having less than a quarter of the population. The recent release of the transcript of the Ukrainian National Security and Defence Council meeting the day after Russia began the annexation of Crimea (28 February 2014) showed just how easy it had been for the Russians to take over the peninsula. The new Minister of Defence Ihor Tenyukh spells out the situation: 'I'll speak frankly. Today we have no army. It was systematically destroyed by Yanukovych and his entourage (Rettman 2016).' Ukraine could mobilise only 5,000 troops and needed these to defend Kyiv.

\section{Is Lukashenka Out-of-step with Public Opinion?}

For reasons of personal survival and raison d'état, Lukashenka has asserted his relative independence since 2014. He has claimed that 'Belarus is not part of the Russian world' (Novaia gazeta 2015). He has promised that 'every Belarusian can rest assured that no one will ever be allowed to destabilize the situation in the country, violate its sovereignty and integrity' (Website of the President of Belarus 2016) and 'Belarus will not allow itself to be drawn into any political adventures' (Minsk-Novosti 2016). His 2010 election slogan 'For a Strong and Prosperous Belarus' was changed in 2015 to 'For the Future of Independent Belarus!' His 2015 election programme co-opted the nationalist argument that: 'Two decades ago, we started to build a new country - the first independent Belarusian state in history. For centuries, we have walked towards independence. History did not spare us. She did not give us an easy path. Our soil does not possess fabulous wealth - and we have always gained our bread with hard but honest work. They have tried to conquer us from outside and divide us inside.' And he defined his 'first important task' as ensuring that 'BELARUS WILL ALWAYS BE FREE AND INDEPENDENT! (Belarus Segodnia 2015)'.

But public opinion in Belarus has moved in contradictory directions. On the one hand, Belarusians want stability. Ordinary Belarusians tend to see the trope of Ukraine's 'Maidan' as a threat to order rather than a path to liberty; only $10 \%$ supported possible public protests before the 2015 election (Shraibman 2015). Only 15\% would join in even economic protests (IISEPS 2015a). The fear of unrest is widespread (Bohdan 2015).

According to a June 2015 poll, only $23.2 \%$ of Belarusians viewed the fall of Yanukovych positively; $63.2 \%$ were negative. A striking $50.9 \%$ consider the new 
Ukrainian government 'fascist', and $15 \%$ do not think that Petro Poroshenko is a legitimate president of Ukraine (Mojeiko 2015a). (Nearly all the opinion polls quoted are by IISEPS, the Independent Institute of Socio-Economic and Political Studies. It has a bad habit of asking leading questions, but was still the best polling organisation in Belarus. It was ordered to be closed in 2016). A majority, 54.7\%, of respondents considered Yanukovych's removal a coup-d'état, while only 27.7\% thought to be 'a fair retribution for the bloodshed that occurred' (Smok 2014). Only $15.5 \%$ of Belarusians said they might take part in a hypothetical Belarusian Maidan; $10.7 \%$ said they would side with the authorities; while by far the biggest number, 65.3\%, would remain neutral (Yeliseyeu 2014).

When asked in June 2015 what they would do 'If Russia tried to annex Belarus' or part of Belarus, only 18.7 per cent said they would 'resist with arms', and only 12.1 per cent would 'welcome the changes'. A massive 52.8 per cent said they would 'try to adapt to the new situation' (IISEPS 2015b).

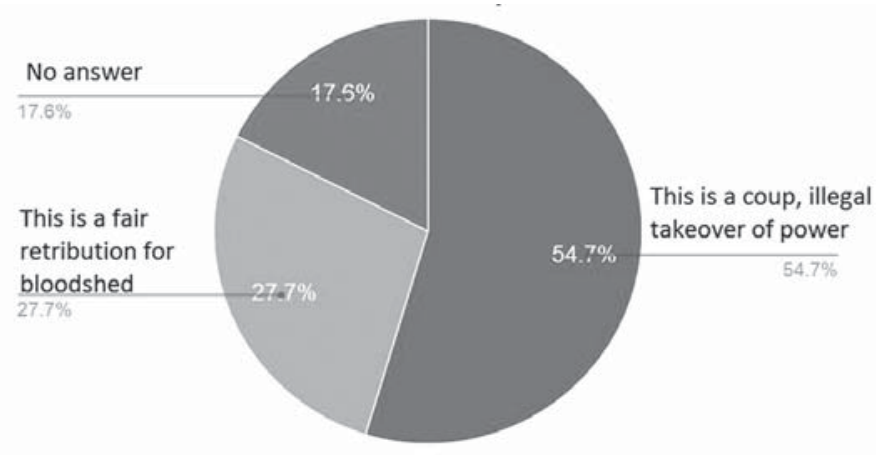

FIGURE 1: Would you like events similar to in Ukraine to happen in Belarus?

(Source: Smok 2014)

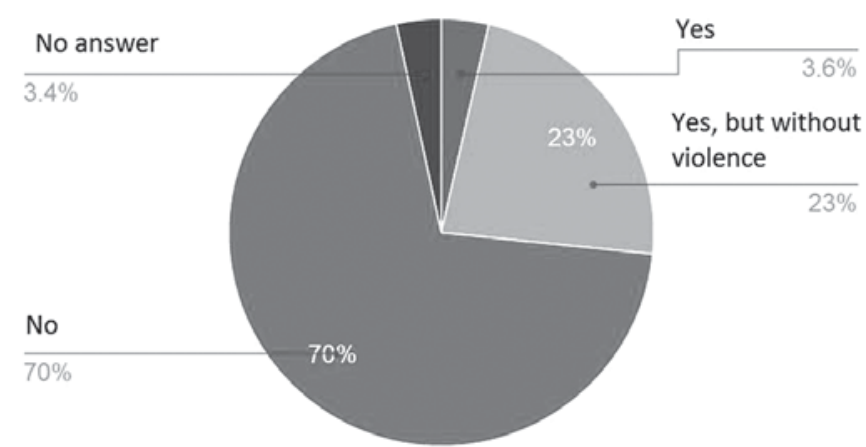

FIGURE 2: If events similar to Ukraine happened in Belarus, would you take part in them? (Source: Smok 2014) 


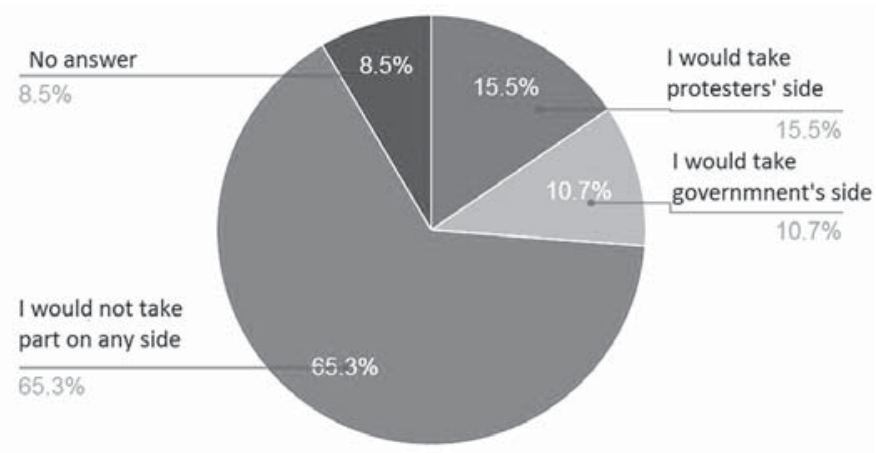

FIGURE 3

When asked another strongly leading questions after Russia's annexation of Crimea in the summer of 2014, 26.9\% of Belarusians agreed that it was 'imperial seizure, annexation', compared to $62.2 \%$ who chose the option that it was 'the return of Russia of Russian lands, the restoration of historical justice'. When asked to assess the situation in Donetsk and Luhansk $65.5 \%$ endorsed the chosen wording that it is a popular protest against illegitimate power', as against $23.2 \%$ who opted for the description of the events as 'rebellion (miatezh), organised by Russia' (IISEPS 2014a).

\section{Sobering up. A little}

What would you do if Russia tried to annex all or part of Belarus' territory?

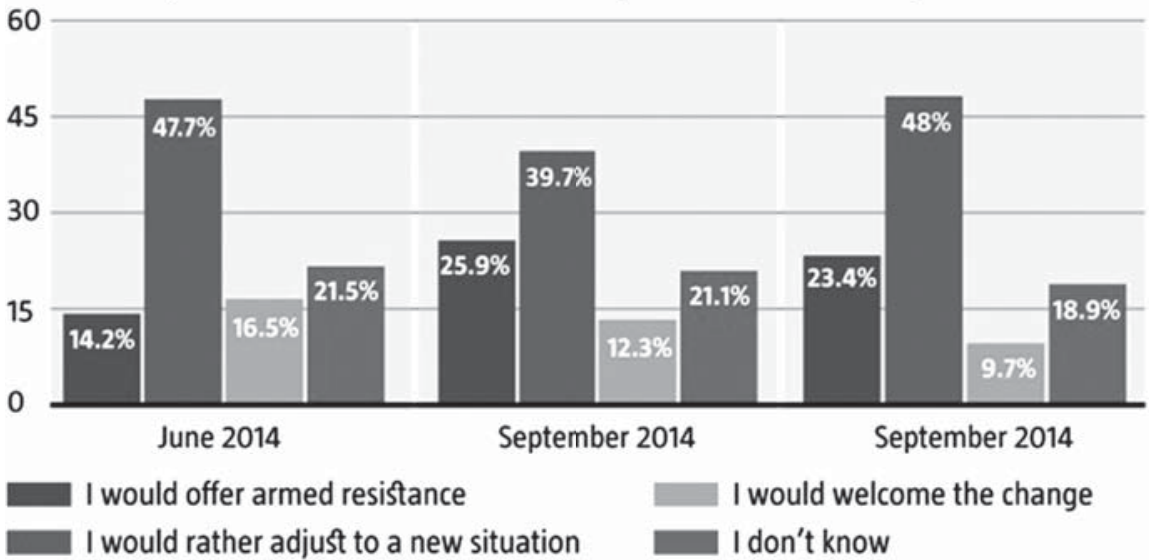

FIGURE 4: Source: A poll by the Independent Institute of Socio-economic and Political Studies (IISEPS)

The idea of the 'Russian world', which Putin used to justify the annexation of Crimea, is regarded positively by $32.3 \%$ of Belarusians and $15.1 \%$ are negative, though again $44.8 \%$ are indifferent (IISEPS 2015c). 
Support for the EU dropped to 25\% in 2014; while in Ukraine, according to Pew, it has gone up to $67 \%$ (Simmons 2015). Support for rival integration projects with the West and with Russia had been surprisingly even in Belarus before 2014. In fact, foreign policy preferences in Belarus might best be treated as a dependent variable - a relatively fluid category determined as much by political ebb-and-flow as the other way around (White and Feklyunina 2014). IISEPS have a longstanding question 'If you had to choose between integration with Russia and joining the European Union, what choice would you make?'

Answers have not been set in stone but have tended to follow whatever seemed the most feasible foreign policy option at the time. Looking at the period either side of the 2010 election, support for integration with Russia fell from $35.7 \%$ in December 2008 to a low of $29 \%$ in December 2011, as relations with Russia deteriorated; rising back a little as relations got back on track, but then falling again after 2014. Support for the EU correspondingly rose to a high of $48.6 \%$ in March 2011 - for the first time considerably higher than support for Russia - and then fell back to a low of $25.1 \%$ in June 2015 (IISEPS 2015d). A tentative explanation would be that economic concerns crowded out security concerns in 2011, making the EU relatively attractive, but security fears intruded after 2014.

In fact, the number of 'don't knows' may be going up. In a December 2015 IISEPS survey, only $19.8 \%$ would vote to join the EU, and $29.7 \%$ would support the integration of Belarus and Russia. So the number of neutrals and don't knows was almost half.

This is even clearer when it comes to attitudes towards the war in Ukraine: $77 \%$ of Belarusians oppose any involvement on either side (IISEPS 2014b). A new law in 2016 made it an offence for Belarusian citizens to fight on either side (Drakakhrust 2016a). Lukashenka has dragged his feet on the proposed Russian air base (Belarus is home to two Russian 'obyekty', a naval communications centre at Viliejka and a radar base at Hancavičy, but no equivalent of the Black Sea base from which Russia launched its coup in Crimea). Interestingly, many Belarusians agree that a base might destabilise more than it protects - in one poll only $27 \%$ of respondents backed the base idea, while $33.9 \%$ were opposed and $31.2 \%$ were indifferent (Drakakhrust 2016b).

But support for the Russian position and the Russian version of events is still strong. Most Belarusians watch Russian TV. According to one analysis, ' $73.1 \%$ of respondents from Belarus responded in December 2014 that they trusted (to a varying degree) the Russian Media' (Karatch 2016b). State-owned ANT is technically the most popular channel, 'but ANT is popular because of the Russian TV shows that it rebroadcasts. The top five most viewed ANT broadcasts include four Russian and one joint Belarusian-Russian show' (Astapenia and Balkunets 
$2016,18)$. On the other hand, the number watching Russia TV has fallen from $90 \%$ to $80 \%$ in two years (Astapenia and Balkunets 2016, 19). It will be interesting to see if state propaganda on Belarusian TV and other media can shift public opinion in a more 'statist' direction.

\section{National Identity}

Lukashenka's defence of independence was enough to disarm some, if not all, of the traditional opposition. Unlike 2010, there were few calls for protests during the 2015 election, in case Russia used a 'Belarusian Maidan' as an excuse to intervene (tut.by 2015). Though part of the 'new moderate' opposition was accused by the old radical opposition of covert links with, or support from, the presidency (Rutkowski, Rychły and Zaniewicz 2016). Tentative moves to row back on Lukashenka's neglect of Belarusian language and culture were also clearly designed to further this rapprochement (Mojeiko 2015b).

It was significant that the two symbolic opposition members 'allowed' to win seats in the 2016 parliamentary elections represented these two wings - the moderate and the cultural opposition. But how far Lukashenka can take this managed rapprochement remains to be seen. Steps towards political technology pluralism have always been likely. But as critic Aliaksandr Klaskoŭski has pointed out, Lukashenka is "afraid of developing national self-consciousness because this will strengthen civil society, which is critical of his regime. It talks a lot about patriotism," he continues, "but real as opposed to state-controlled patriots make it uncomfortable", (Goble 2016).

Belarus does not yet have a strong national identity that would automatically align both society and elites with Lukashenka in his defence of independence. What might be dubbed 'soft' alignment with Russian culture is still stronger than 'soft' alignment with the Western version of the Belarusian idea. Lukashenka has increasingly represented a 'creolic' middle ground, but not one that is capable of transcending this fundamental divide. But it's time to look properly at questions of state -led nation-building. What ideas and tropes are slowly being attached to the otherwise empty slogan of 'For Belarus!'? The strength of Lukashenka's 'imagined community' is about to be sorely tested. And Lukashenka faces a classic Catch-22 problem: any moves he takes to nationalise Belarus would be perceived as hostile by Russia.

\section{Is Lukashenka Out-of-step with the Elite?}

After more than twenty years in power, the West is belatedly developing a better base in 'Lukashenka studies'. We know very little, however, about the Belarusian 
elite. We do not know how loyal the state apparatus is to Lukashenka. We don't know enough about the sticks and carrots that keep the elite loyal. We don't know enough about the whys and wherefores of the periodic purging of apparent loyalists - the case against leading businessman Jury Čyž being only the latest (Bohdan and Astapenia 2016).

We don't know enough about the key mechanisms of state control. Recent works by Balmaceda and Lucan Way have identified some key institutions, but we don't know much about their internal workings. The Committee for Government Control (KGK), for example, oversees the bureaucracy and a network of semiautonomous businesses. The Presidential Business Administration (UDP) and its Property Management Division act as leaseholders for almost the entire economy. The off-budget Presidential Fund is allegedly used to control key income streams from oil and arms sales. Balmaceda estimates its size at \$3 billion to \$10 billion per annum (Balmaceda 2014b, 102). Lukashenka allegedly takes a 'cut' on most business deals (Balmaceda 2014b, 111); - which is potentially the thin end of the wedge away from distributional authoritarianism and towards the kind of topheavy corruption seen in Ukraine under Yanukovych.

But we don't know how much scope there is for 'informal practices' within the elite - for example, who gets the rent from the shady system of semi-independent oil brokers, davaltsy or neftetreideri, half-in and half-out of the sistema.

We don't know enough about the Belarusian siloviki and their ultimate loyalties (Liakhovich 2012). Clearly they are not totally hollowed out and penetrated by agents, as the army and SBU were in Ukraine under Yanukovych. But many are ethnic Russians. And many more served or trained in Russia (many officers and special forces are graduates of the Ryazan Higher airborne Command School and the Special Intelligence faculty of the Novosibirsk school) (Tynchenko 2015). How much do joint exercises and socialisation matter? Aliaksandr Aliesin published an article in March 2015, entitled 'Belarusian army to be retrained for hybrid warfare' - which you can read either way. It's a statement of intent, but also an admission of just how far it was previously integrated with its Russian equivalent.

It would be good to know more about Viktar Lukashenka's powers over the siloviki, and how exactly the three branches of KGB, Operational and Analytical Center and the Investigative Committee relate to one another.

Finally, and possibly most importantly, we don't know enough about the nonmaterial loyalty of the elite. Lucan Way has identified a long-term weakness for Lukashenka in the lack of dominant party to bind the elite together and represent its interests (Way 2015). The sheer lack of meaningful public politics in Belarus obviously matters for mass opinion, but it's also a problem for elites. The weakness 
of Belarusian nationalism, even after twenty two years of Lukashenka, is clearly also a problem.

A study by Matsuzato in 2004 showed how Lukashenka's 'rotation of cadres' seems to be an effective way of preventing the formation of bureaucratic cliques in the regions (Matsuzato 2004). ${ }^{1}$ The downside of this policy might be that rotating cadres fail to put down deep roots.

\section{Conclusions}

There has been a triple shift since 2014. First, Russia is much more aggressive towards all of its neighbours. But it is also more demanding of them. Despite economic pressures, Russia is not retrenching (Secrieru 2016); but it is looking for more value-for-money in all its relationships. The old subsidy regime cannot be as generous as it was, and, with Russia struggling to subsidise Crimea and the Donbas, it is pretty clear that it could not afford to pay all the bills of an extra nine and a half million Belarusians.

Second, Lukashenka has shifted in a more statist direction. Third, part of the old opposition has gone with him. But the biggest unknown is the things that may have changed the least. Public opinion in Belarus is shaped by Russian media and remains strongly Russophile. This is only changing slowly. The Belarusian public is also instrumental. There is support for paternalism from whatever source (IISEPS opinion polls do not directly address the question of whether Belarusians care who provides the welfare they undoubtedly value). There is only limited evidence that the population shares the elite's concerns about national security.

One lesson from eastern and southern Ukraine is that it is the moment of conflict that strengthens loyalty to the existing state. Pro-Ukrainian sentiment in the east and south has risen, but not because of the three months of the Maidan, largely because of the two years of war that followed. Belarus has not been invaded, but a sense of threat, and a desire to stay out of conflict, has led to a certain closing of ranks.

There is also some inertia in the system after twenty two years of Lukashenka. The sinews of the state are stronger than they were in Yanukovych's Ukraine. It would be much easier for Russia to impose their own guy at the top rather than break the bonds between the leader and the elite, or between the leader and society. So Belarus may have some strength in reserve.

\footnotetext{
1 Kimitaka Matsuzato, 'A Populist Island in an Ocean of Clan Politics: The Lukashenka Regime as an
} Exception Among CIS Countries’, Europe-Asia Studies, vol. 56, no. 2, March 2004. 


\section{References}

Aliachnovič, Alieś, 2015. How Russia’s Subsidies Save the Belarusian Economy, Belarus Digest, 26 August. Available at: <http://belarusdigest.com/ story/how-russias-subsidies-save-belarusian-economy-23118>

Astapenia, Ryhor and Balkunets, Dzmitry, 2016. Belarus-Russia Relations after the Ukraine Conflict, Ostrogorski Centre Analytical Paper, no. 5, 1 August, p. 18. Available at: <http://belarusdigest.com/story/analytical-paper-belarus-russiarelations-after-ukraine-conflict-26617>

Balmaceda, Margarita, 2014a. Energy Policy in Belarus: Authoritarian Resilience, Social Contracts, and Patronage in a Post-Soviet Environment, Eurasian Geography and Economics, vol. 55, no. 5, pp. 514-36, p. 515.

Balmaceda, Margarita, 2014b. Living the High Life in Minsk: Russian Energy Rents, Domestic Populism and Belarus' Impending Crisis. Budapest: Central European University Press, p. 120.

Belarus Segodnia, 2015. For the Future of Independent Belarus!, 16 September. Available at: <www.sb.by/prezident-belarusi/article/za-budushchee-nezavisimoybelarusi.html $>$

Bohdan, Siarhei and Astapenia, Ryhor, 2016. Why Belarus KGB Detained the Country's Former Top Businessman', Belarus Digest, 18 March. Available at: $<$ http://belarusdigest.com/story/why-belarus-kgb-detained-countrys-former-topbusinesman-25014>

Bohdan, Siarhei, 2015. Why Ukraine Failed to Revolutionize Belarus, Belarus Digest, 28 May. Available at: <http://belarusdigest.com/story/why-ukraine-failedrevolutionize-belarus-22802>

Coalson, Robert and Jozwiak, Rikard, 2015. Worried about Moscow, Belarus's Lukashenka Drifts toward Brussels, RFE/RL, 27 January. Available at: <www.rferl. org/a/belarus-lukashenka-drifts-toward-brussels/26816183.html>

Deutsche Welle, 2015. Lukashenko Dashes Hopes of Economic Reform at Inauguration, 6 November. Available at: <www.dw.com/en/lukashenko-dasheshopes-of-economic-reform-at-inauguration/a-18833472>

Drakakhrust, Yury, 2016a. Whose Side Is Belarus on Anyway?, Open Democracy, 12 May. Available at: <www.opendemocracy.net/od-russia/yurydrakakhrust/whose-side-is-belarus-on-anyway>

Drakakhrust, Yury, 2016b. Public Opinion: Back to Reality, Belarusian Yearbook 2016. Available at: <http://nmnby.eu/yearbook/2016/en/page23.html> 
Goble, Paul, 2016. Minsk Fears Moscow May Organize Hybrid War and Coloured Revolution in Belarus, Eurasian Daily Monitor, vol. 13, no. 116, 28 June. Available at: <https://jamestown.org/program/minsk-fears-moscow-mayorganize-hybrid-war-and-color-revolution-in-belarus/>

IISEPS, 2014a. Vsesil'na li propaganda?, 5 July. Available at: $<$ http://old.iiseps. org/06-14-08.html>

IISEPS, 2014b. Ukrainskii kompas dlia geopoliticheskikh poliusov Belarusi, September. Available at: <www.old.iiseps.org/09-14-04.html>

IISEPS, 2015a. Dislike for the Power Doesn't Transform into a Wish to Protest. Available at: <www.iiseps.org $/$ ?p=861\&lang=en $>$

IISEPS, 2015b. The Most Important Results of the Public Opinion Poll in June 2015. Available at: $<$ www.iiseps.org/?p=2678\&lang $=\mathrm{en}>$

IISEPS, 2015c. The Most Important Results of the Public Opinion Poll in December 2015, 29 December. Available at: <www.iiseps.org/?p=3865\&lang=en $>$

IISEPS, 2015d. Khorosha Evropa, da ne pro nas. Available at: <www.old. iiseps.org/06-15-05.html>

Ioffe, Grigory and Yarashevich, Viachaslau, 2011. Debating Belarus: An Economy in Comparative Perspective, Eurasian Geography and Economics, vol. 52 , no. 6 .

Ioffe, Grigory, 2014. Reassessing Lukashenka: Belarus in Cultural and Geopolitical Context. Houndmills and New York: Palgrave Macmillan.

Karatch, Olga, 2016. Opinion: Four Russian Instruments of Control over Belarus, Belarus Digest, 13 September. Available at: <http://belarusdigest.com/ story/opinion-four-russian-instruments-control-over-belarus-27210>

Liakhovich, Andrei, 2012. The Role of Security Services in Belarus Politics, Belarus Digest, 14 March. Available at: <http://belarusdigest.com/story/rolesecurity-services-belarus-politics-8331>

Matsuzato, Kimitaka, 2004. A Populist Island in an Ocean of Clan Politics: The Lukashenka Regime as an Exception Among CIS Countries, Europe-Asia Studies, vol. 56 , no. 2 .

Minsk. Novosti, 2016. A. Lukashenko: Belarus’ za gody nezavisimosti ne dala vtianut' sebia ni v odnu politicheskuiu avantiuru, 3 July. Available at: <http:// minsknews.by/blog/2016/07/03/a-lukashenko-belarus-za-godyi-nezavisimosti-nedala-vtyanut-sebya-ni-v-odnu-politicheskuyu-avantyuru/> 
Mojeiko, Vadim, 2015a. Post-Maidan Belarus: Demand for Stability and More Belarusianness, Bell, no. 2. Available at: <www.eesc.lt/uploads/news/id849/ Bell\%20Nr.2_2015_.pdf>

Mojeiko, Vadim, 2015b. Soft Belarusization: a New Shift in Lukashenka's Domestic Policy?, Belarus Digest, 21 April. Available at: <http://belarusdigest. com/story/soft-belarusization-new-shift-lukashenkas-domestic-policy-22434>

Novaia gazeta, 2015. Lukashenko: Belorussiia ne chast" "russkogo mira", 29 January. Available at: <www.novayagazeta.ru/news/2015/01/29/109671lukashenko-belorussiya-150-ne-chast-171-russkogo-mira-187>

Popov, Eduard, 2016. Popov: «Lukashenko Is Repeating Yanukovich's Mistakes», Fort Russ, 3 July. Available at: <www.fort-russ.com/2016/07/popovlukashenko-is-repeating.html>

Pranevičiūtè-Neliupšienè, J. and Maksimiuk, Z., 2014. Authoritarian Bargain in Belarus: The System of Social Benefits as a Factor of Regime Stability, in Pranevičiūtè-Neliupšienè et al eds., Belarusian Regime Longevity: Happily Ever After. Vilnius: Vilnius University Publishing House, pp. 124-156.

Rettman, Andrew, 2016. West Told Ukraine to Abandon Crimea, Document Says, EU Observer, 24 February. Available at: <https://euobserver.com/foreign/132425>

Rutkowski, Bartosz, Rychły, Marcin and Zaniewicz, Maciej, 2016. The Complicated Story of the Belarusian Opposition, New Eastern Europe, no. 1 (January-February), pp. 131-137.

Secrieru, Stanislav, 2016. Why Russia Does not Retrench, New Eastern Europe, no. 5.

Shraibman, Artyom, 2015. What Makes the 2015 Belarus Presidential Campaign So Different?, Belarus Digest, 4 August. Available at: <http://belarusdigest.com/ story/what-makes-2015-belarus-presidential-campaign-so-different-22989>

Simmons, Katie, Stokes, Bruce and Poushter, Jacob, 2015. Ukrainian Public Opinion: Dissatisfied with Current Conditions, Looking for an End to the Crisis, Pew Research Center, 10 June. Available at: <www.pewglobal.org/2015/06/10/3ukrainian-public-opinion-dissatisfied-with-current-conditions-looking-for-an-endto-the-crisis/>

Smok, Vadzim, 2014. New Polls: Belarusians Support Lukashenka and Do Not Want an Euromaidan, Belarus Digest, 2 May. Available at: <http://belarusdigest. $\mathrm{com} /$ story/new-polls-belarusians-support-lukashenka-and-do-not-wanteuromaidan-17707> 
Tut.by, 2015. BPF Is Calling to Drop the Maidan Idea and Nominate Kastusiou for Presidency, 7 March. Available at: <http://news.tut.by/politics/438685.html>

Tynchenko, Yaroslav, 2015. Muscle Flexing in the North', Ukrainian Week, no. 4 (April), pp. 40-43. Available at: <http://i.tyzhden.ua/content/ photoalbum/2015/04_2015/27/Book4.pdf>

Way, Lucan, 2015. Pluralism by Default: Weak Autocrats and the Rise of Competitive Politics. Baltimore: John Hopkins University Press.

Website of the President of Belarus, 2016. Belarus President's Speech at the Independence Day Military Parade, 3 July. Available at: <http://president.gov.by/ en/news_en/view/belarus-presidents-speech-at-the-independence-day-militaryparade-13963/>

White, Stephen and Feklyunina, Valentina, 2014. Identities and Foreign Policies in Russia, Ukraine and Belarus: the Other Europes. Basingstoke and New York: Palgrave Macmillan.

Yarashevich, Viachaslau, 2014. Political Economy of Modern Belarus: Going against Mainstream? Europe-Asia Studies, vol. 66, no.10, pp. 1703-1734.

Yeliseyeu, Andrei, 2014. Protest Activity in Ukraine and Belarus and Belarusian Public Attitude towards Maidan, Bell, no. 2. Available at: <www.eesc.lt/uploads/ news/id728/Bell\%202014\%202\%20(44).pdf> 